\title{
27. LITHOSTRATIGRAPHY, FRACTURING, AND FLUID FLOW IN THE UPPER OCEANIC CRUST ${ }^{1}$
}

\author{
L.O. Boldreel, ${ }^{2}$ P.K.H. Harvey, ${ }^{3}$ P. Pezard,${ }^{4}$ and G.J. Iturrino ${ }^{5}$
}

\begin{abstract}
At the time of reentry into Hole 504B during Leg 140 a major temperature inversion and associated temperature gradient minimum was recorded between 283 and $288 \mathrm{mbsf}$, together with a significant minimum at $325 \mathrm{mbsf}$. Neither of these temperature anomalies was observed at the time of reentry during Leg 137, only a few months previously. The temperature inversion is located slightly below the top of the basement; the minimum at $325 \mathrm{mbsf}$ is located slightly below Unit $2 \mathrm{D}$. At both depth intervals horizontal fracturing is extensive, and it is suggested that fluid could have entered the borehole, or been trapped within the fractured rock, at these two locations. In the pillow lava section (274-405 mbsf, corresponding to seismic Layer $2 \mathrm{~A}$ ) horizontal fracturing dominates in clearly defined zones, and here the variation in temperature gradient could result from fluid flow or differential recovery following inflow during Leg 137 . Thus the temperature variations in the basement are apparently favored by the presence of the horizontal fracturing. The pillow lava sequence ( $405-550 \mathrm{mbsf}$ corresponding to a part of seismic Layer $2 \mathrm{~B}$ ) is characterized by zones of either vertical or horizontal fracturing. The stepwise behavior of the temperature gradient suggests a correlation to the horizontal fractured zones, and some fluid flow or differential recovery of the Leg 137 inflow is present.
\end{abstract}

\section{INTRODUCTION}

Hole 504B is drilled into 5.9-m.y.-old oceanic crust in the eastern equatorial Pacific Ocean about $200 \mathrm{~km}$ south of the spreading axis of the Costa Rica Rift at a water depth of $3460 \mathrm{~m}$. Leg 140 was the seventh Deep Sea Drilling Project (DSDP)/Ocean Drilling Program (ODP) expedition to occupy Hole 504B (DSDP Legs 69, 70, 83, and 92; ODP Legs 111, 137, and 140). Through the years, these legs have provided a wealth of scientific results concerning the upper oceanic crust (CRRUST, 1982); Cann, Langseth, Honnorez, Von Herzen, White, et al. (1983); Anderson et al. (1982); Anderson, Honnorez, Becker, et al. (1985); Leinen, Rea, et al. (1986); Becker, Sakai, et al. (1988, 1989a, 1989b); Becker, Foss, et al. (1992); and Dick, Erzinger, Stokking, et al. (1992).

At the end of Leg 140 the hole extended through $274.5 \mathrm{~m}$ of sediment and $1725 \mathrm{~m}$ of basement, the latter including the extrusive pillow lavas and a sheeted dike complex. The hole is cased to 276 mbsf, just below the sediment/basement contact. The basement includes $571.5 \mathrm{~m}$ of pillow lavas and minor flows that are part of the extrusive pillow lavas (equated to seismic Layers 2A and 2B) and a $209 \mathrm{~m}$ transition zone entering the sheeted dike complex (equated to seismic Layer 2C) (Fig. 1). This basement sequence is compatible with ophiolite studies.

Temperature measurements at the time of reentry during Leg 137 and 140 resulted in some exciting observations concerning the geothermal and hydrological stage of the hole, which previously has been described in overview by Gable et al. (1989). This is particularly the case in the uppermost $500 \mathrm{~m}$, where unexpected values occurred (Fig. 1). These were ascribed to convection in the permeable, upper-500-m part of the basement beneath an impermeable sediment cover that provides an excellent seal against pervasive hydrothermal circulation.

\footnotetext{
${ }^{1}$ Erzinger, J., Becker, K., Dick, H.J.B., and Stokking, L.B. (Eds.), 1995. Proc. ODP Sci. Results, 137/140: College Station, TX (Ocean Drilling Program).

${ }^{2}$ Geological Survey of Denmark, Thoravej 8, DK-2400 Copenhagen, NV, Denmark

${ }^{3}$ Borehole Research, Department of Geology, University of Leicester, Leicester, LEI $7 \mathrm{RH}$, United Kingdom.

${ }^{4}$ Institut Méditerranéan de Téchnologie, Téchnopole de Château-Gombert, 13451 Marseille Cedex 13, France.

${ }^{5}$ Rosenstiel School of Marine and Atmospheric Science, Division of Marine Geology and Geophysics, University of Miami, 4600 Rickenbacker Causeway, Miami, FL 33149
} 1098. U.S.A.
However, below $550 \mathrm{~m}$ the measured temperature profile at the reentry of Leg 140 mimics temperature values corresponding to Legs 137 and 111 (Fig. 1).

This paper is concerned with the temperature profile measured during the reentry of Leg 140 and its correlation with fracture porosity obtained from electric and standard gamma-ray logs measured during Leg 111 (Becker, Sakai, et al., 1988), as well as to the lithologic units described during Leg 69 (Cann, Langseth, Honnorez, Von Herzen, White, et al., 1983) in the upper $570 \mathrm{~m}$ of the basement.

\section{PREVIOUS MEASUREMENTS AND DATA COLLECTING}

During the past 11 years temperature vs. depth profiles have been measured in Hole 504B on seven occasions (Fig. 1). The temperature was measured under equilibrium or near-equilibrium conditions from drilling disturbance, using various tools and procedures, when the hole was reentered on successive legs (Becker et al., 1983a, b; 1985 Becker, Sakai, et al., 1988; Gable et al., 1989; Becker, Foss, et al., 1992; Dick, Erzinger, Stokking, et al., 1992). First in October 1979, DSDP Leg 69 logged temperature readings in the upper $200 \mathrm{~m}$ of the $562 \mathrm{~m}$ drilled in the basement section. Two months later, DSDP Leg 70 reentered the hole and measured the temperature gradient to a depth of 836 mbsf. Approximately 2 years later, in November 1982, DSDP Leg 83 obtained temperature measurements through most of the pillow lava section present in Hole 504B. In April 1983, following previous procedures, DSDP Leg 92 obtained a sequence of temperature readings and water samples in steps down the hole, with no pumping. These measurements were designed to reassess the extraordinary downhole flow of ocean bottom water into a shallow basement reservoir and the predominantly conductive geothermal gradient extending from 400 to $1350 \mathrm{mbsf}$.

The advent of the Ocean Drilling Program in the mid 1980s created the opportunity to reenter Hole 504B during Leg 111 in August 1986. At this time, the results from the temperature logs showed that the hole was reaching thermal equilibrium with no apparent downhole flow of ocean bottom water. In April 1991, Leg 137 returned to the hole and found that the temperature readings were significantly lower (Becker, Foss, et al., 1992) with a characteristic inflection in the profile that was as pronounced as that observed during the previous DSDP legs (Fig. 1). In October 1991, Leg 140 logged temperature readings for the purpose of monitoring the down- 


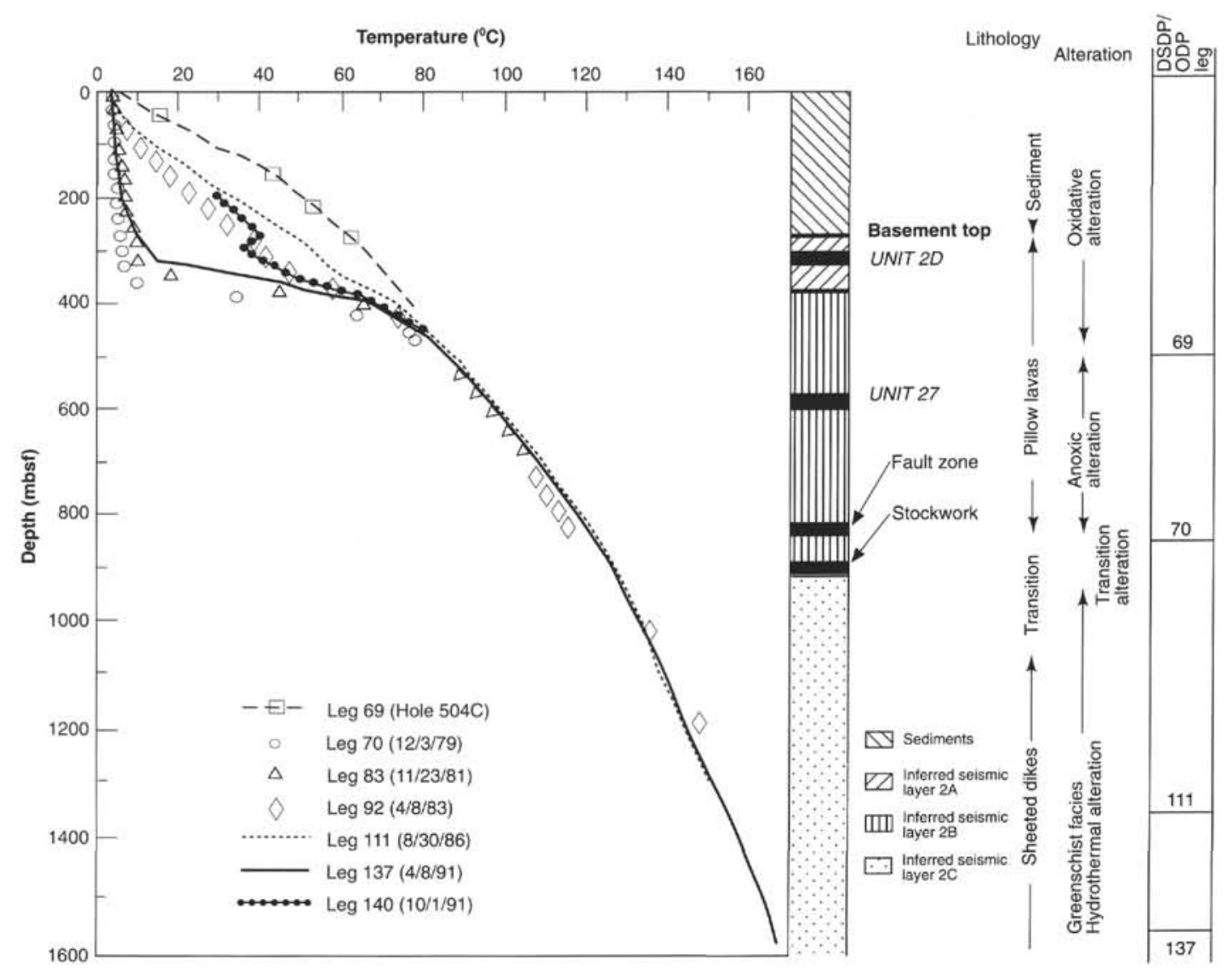

Figure 1. Composite of temperature logs obtained in Hole 504B during Legs 69 (Hole 504C), 70, 83, 92, 111, 137, and 140 showing the temperature vs. depth profiles during reentry. Also shown are pronounced intervals in the well, the lithology of Hole 504B, and the alteration environment.

hole flow detected during the previous leg and also to assess the degree to which the water had warmed up.

During the reentry of Leg 140 the temperature was measured using a high-resolution temperature tool designed at the Bureau de Recherche Géologiques et Minières (BRGM), France. The tool uses accurately calibrated thermistors housed in a 5-mm-diameter tube in the lower part of the sonde. Temperature is determined from the resistance of the thermistors. For the logging operations during Leg 140 , measurements were taken at $15 \mathrm{ft} / \mathrm{min}(4.57 \mathrm{~m} / \mathrm{min})$, which provided temperatures every $0.1 \mathrm{~m}$. The logging operation was conducted from $200 \mathrm{mbsf}$ to $550 \mathrm{mbsf}$, a section including the lower part of the cased section and that part of the pillow lava located above Unit 27 (Fig. 1). At about 500 mbsf temperatures approached those measured during reentry on Leg 111 and 137 .

The stability of the downhole probe was checked during a 16-min stationary recording at $550 \mathrm{mbsf}$ following reentry of the hole (Fig. 2). These stationary measurements can be summarized as follows: mean temperature: $91.349^{\circ} \mathrm{C}$; standard deviation: 0.0339 ; and number of measurements: 744 . There was an apparent periodicity over the first few minutes, which we attributed to small-scale oscillations in the borehole due to displacement caused by the introduction of the pipe/ temperature tool. After about $9 \mathrm{~min}$ the profile settled down. The summary statistics for the last $8 \mathrm{~min}$ are: mean temperature: $91.378^{\circ} \mathrm{C}$; standard deviation: 0.0164 ; number of measurements: 326 . We consider the readings from the last $8 \mathrm{~min}$ to be more representative of the measurement precision of the temperature tool than the first $8 \mathrm{~min}$.

\section{DATA ANALYSIS}

The three temperature profiles recorded in Hole 504B during Leg 111, 137, and 140 are shown in Figure 1. Although the profiles have been recorded strictly during reentry at the beginning of each of the three legs during equilibrium (from prior drilling disturbances) situations over the past 5 years, they show pronounced differences that are thought to reflect the hydrological activity in the upper basement. The profile recorded at the reentry of Leg 111 was considered to be at near equilibrium to the conductive geothermal gradient in the surrounding sediments and uppermost basement (Becker, Sakai, et al., 1988). This equilibrium situation was not constant as the profile recorded at Leg 137 is characterized by low values, which are similar to Legs 70 and 83 , as compared to the profiles from Leg 111 and the later Leg 140. The values at the reentry of Leg 137 are fairly constant down to $320 \mathrm{mbsf}$ and from here on the temperature increases reaching the values at 550 mbsf reported from Leg 111 and Leg 140. The location of a pronounced change in temperature gradient is found just above Unit 2D at 312-325 mbsf and indicates fluid intake. The low values represent a strong downward flow of about $15 \mathrm{~m} / \mathrm{hr}$ corresponding to $1000 \mathrm{~L} / \mathrm{hr}$ (Becker, Foss, et al., 1992) of cold ocean bottom water into the hole, which had not been significantly warmed up at the time of reentry of Leg 137. The profiles recorded at Leg 111 and 140 show a much weaker downflow with a value on the order of $1.2 \mathrm{~m} / \mathrm{h}$ as based on the transient model of Becker et al. (1983a) and Gable et al. (1989).

The profile recorded during Leg 140 shows a pronounced difference from that during reentry on Legs 111 and 137 as the temperature profile reflects a condition between the equilibrium and the downhole inflow situation (Figs. 1 and 3). An interesting feature of the profile is the temperature inversion found at $280-285 \mathrm{mbsf}$, which is the first inversion seen on the temperature profiles so far recorded at the reentry of Hole 504B (Fig. 1). As the downflows are essentially comparable, this anomaly could suggest that cold fluid has entered the hole from the upper basement. This fluid activity at the top of the basement would be in contrast to the previous gradual re-equilibra- 


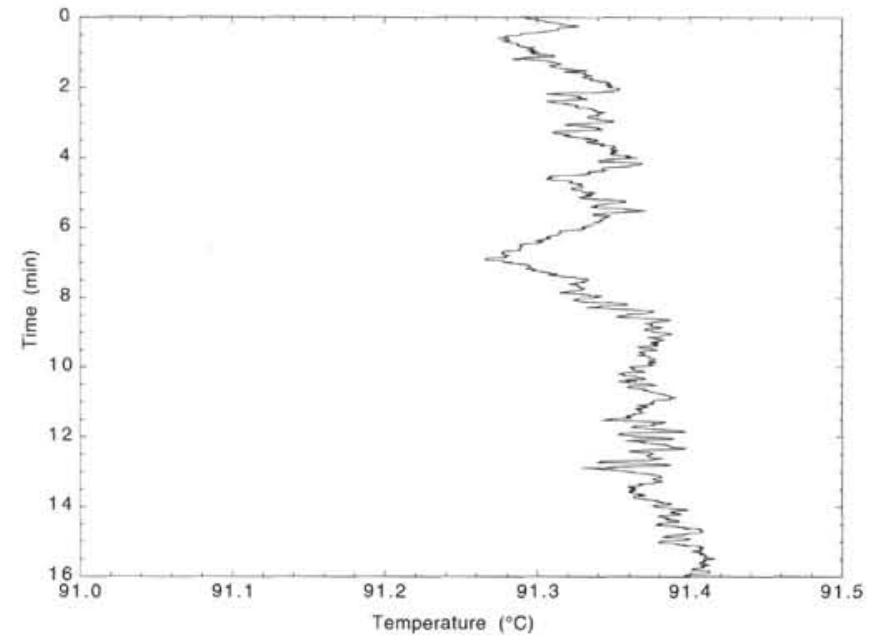

Figure 2. Stationary reading during a $16-\mathrm{min}$ stay at $550 \mathrm{mbsf}$ during reentry of Leg 140 to test the stability of the temperature probe.

tion of the underpressure observed between 1979 and 1986 (Gable et al., 1989). This may result from local tectonic activity such as the re-activation of faults with time to produce new conduits, or might be related to differential recovery from the local cooling produced by the reactivated downflow observed six months earlier.

The three profiles merge at approximately $450 \mathrm{mbsf}$ and then coincide down to $550 \mathrm{mbsf}$ to describe a relatively constant thermal regime down to $1550 \mathrm{mbsf}$ measured during reentry of Legs 111 and 137 (Fig. 1) through the lower part of the pillow lava sequence, the transition zone, and into the sheeted dikes below.

\section{LEG 140 TEMPERATURE PROFILE}

To consider the anomalous behavior of the temperature recorded at Leg 140 the temperature profile is analyzed further (Fig. 3). The temperature increases from $200 \mathrm{mbsf}$ to $260 \mathrm{mbsf}$ (from $26^{\circ} \mathrm{C}$ to $36^{\circ} \mathrm{C}$ ) and stays constant to $280 \mathrm{mbsf}$. From here it drops to $33^{\circ} \mathrm{C}$ at $285 \mathrm{mbsf}$ before increasing to $91^{\circ} \mathrm{C}$ at $550 \mathrm{~m}$.

To examine the more subtle changes in the temperature profile the temperature data were transformed into a temperature gradient curve. The latter is much more sensitive to changes in temperature than a simple temperature profile (Figs. 3 and 4). For purposes of clarity of presentation in Figure 4 the gradient data were smoothed over a 2-m interval using a simple moving average.

The profile can be divided into a number of distinct zones (Fig. 3). At the top of the profile down to $250 \mathrm{mbsf}$ the gradient is rather constant, reflecting the linear increase in temperature. At the basement intersection the gradient is almost constant. A major temperature inversion zone is located immediately below the top of the basement ( 283 to $288 \mathrm{mbsf}$ ) where the temperature gradient reaches its minimum value. Below this zone down to $400 \mathrm{mbsf}$ some minor minima are seen on the gradient curve, among which the largest is at $321 \mathrm{mbsf}$. Between $300 \mathrm{mbsf}$ and $313 \mathrm{mbsf}$ in Unit 2D the gradient is increasing with minor fluctuations, and the maximum values are reached within the underpressured aquifer (Fig. 4), which was detected during Leg 69 from temperature data and packer tests (Anderson and Zoback, 1982; Cann, Langseth, Honnorez, Von Herzen, White, et al., 1983). Here the gradient locally reaches values up to $500^{\circ} \mathrm{C} / \mathrm{km}$. Below this point the gradient, on average, decreases stepwise, corresponding to porosity zones (see below) through the pillow lava sequence down to $550 \mathrm{mbsf}$. An exception is an interval around 505-535 mbsf where an increase is observed.

The relationship between temperature and temperature gradient down to about $250 \mathrm{mbsf}$ is characterized by a steady linear increase in temperature (Fig. 3). Below this point, and moving into the basement, the major temperature inversion with its accompanying minimum on

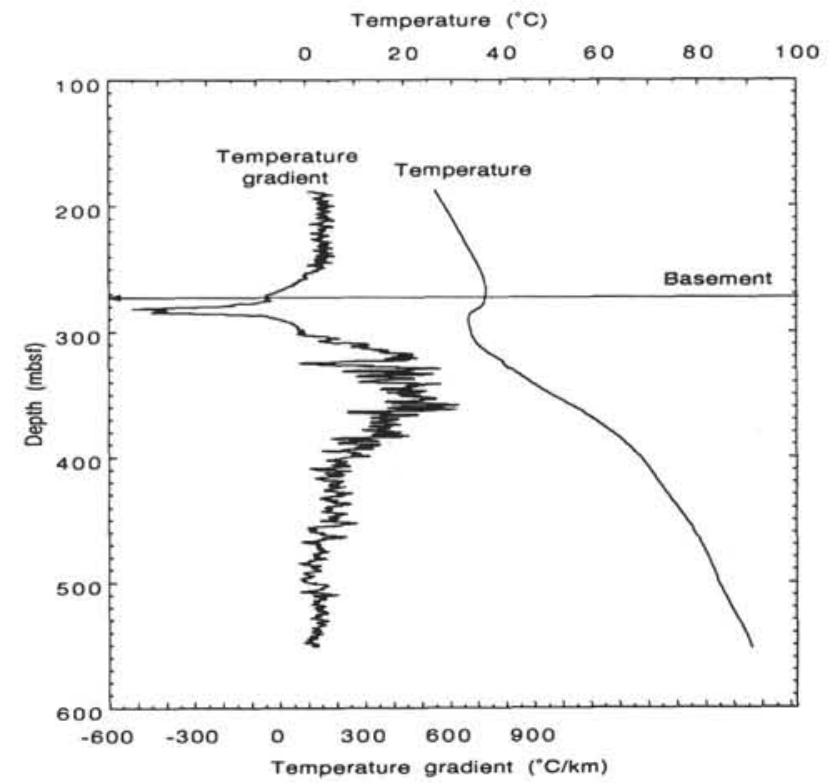

Figure 3. Composite diagram of the temperature vs. depth and the temperature gradient vs. depth profiles recorded on 1 October 1991 during reentry in Hole 504B.

the gradient curve occurs at around $283 \mathrm{mbsf}$. Below this point the gradient shows an overall increase and maximum between about 340 and 370 mbsf. Below the latter depth the gradient gradually decreases to $550 \mathrm{mbsf}$. In the hundred or so meters below the temperature inversion the gradient curve shows a wide but systematic variation.

\section{TEMPERATURE GRADIENT AND FRACTURE POROSITY}

In analyzing the temperature profile it is assumed that the distribution of fractures, including both vertical and horizontal fractures, had an influence on the hydrological circulation in the upper basement, and therefore some relationship between the temperature gradient and fracture porosity profile might be expected. The fracture porosity profile is derived from the analysis of electrical resistivity data obtained by the Dual Laterolog (DLL) on Leg 111 (Becker, Sakai, et al., 1988; Pezard, 1990). A total fracture porosity is calculated from these data by applying Archie's law, and profiles of horizontal and vertical fracture porosity are derived from the differences between the deep-and shallow-penetrating resistivity traces obtained with the DLL (Pezard and Anderson, 1989). The correlation between the total fracture porosity and the temperature gradient obtained at the reentry of Leg 140 was not pronounced. We assumed that the total fracture porosity was too gross a parameter, as we would suspect that the measured temperature profile would be affected differently by fluid flow in vertical and horizontal fractures. In this way we suspected that the total fracture porosity could mask a relationship between fracturing and temperature. Figure 4 shows the calculated horizontal and vertical fracture porosity plotted together with the temperature gradient. Note that the curve representing the vertical fracture porosity has been multiplied by -1 so that it can be distinguished from the horizontal fracture porosity. This allows the relation between the vertical and horizontal fracturing to be presented in a new visual way.

In the uppermost part of the basement above Unit $2 \mathrm{D}$ where the gradient inversion from Leg 140 occurs, horizontal fracturing dominates (Fig. 4). The location of the fluid intake measured on Leg 137 took place where horizontal fracturing dominates slightly above Unit $2 D$. The latter is characterized by a high resistivity value and is considered to be virtually impermeable. The underpressured aquifer (325$355 \mathrm{mbsf}$ ), where the temperature gradient is high, has the greatest 


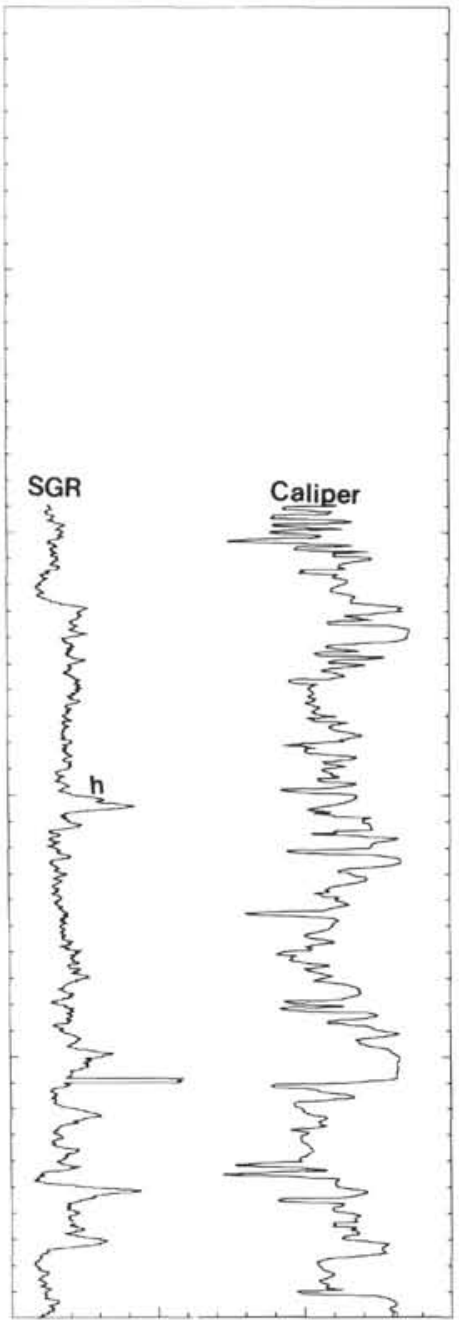

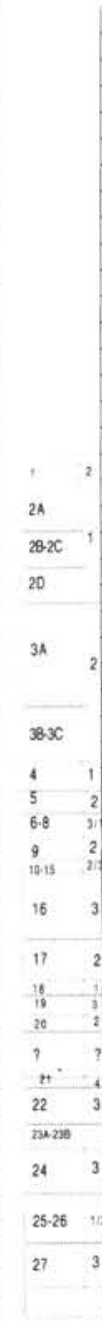

4.00
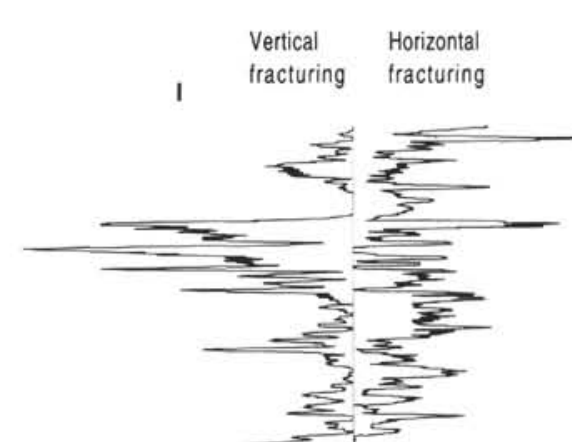

$\rightarrow$

23

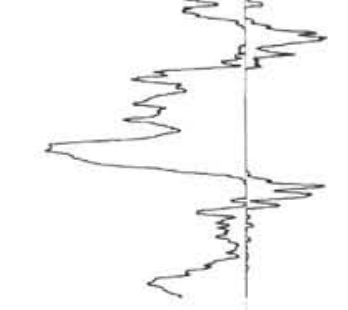

CALIPER (cm)

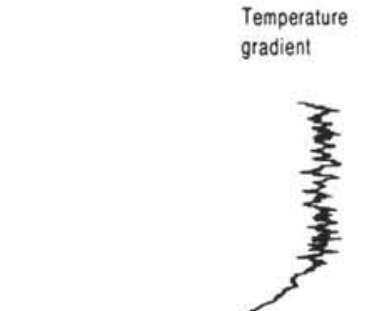

Basement top

Fluid intake observed

Figure 4. Composite diagram showing the temperature gradient vs. depth profile, the fracture porosity vs. depth, caliper log vs. depth, standard gamma-ray log vs. depth, basalt units and basalt lithology vs. depth, and selected intervals in Hole 504B all plotted down to Unit 27. Note that the representation of the vertical fracturing is mirrored with respect to the zero-axis, thus plotted positive to the left (for further explanation see text). 
combined horizontal and vertical fracture porosity. The amount of fracturing is greatest in the upper part of the aquifer where vertical fracturing dominates. In the lower part the horizontal fractures are more important, while the highest values of the temperature gradient are also found in this interval (Fig. 4). At the top of the aquifer a gradient minimum takes place where horizontal fracturing dominates (Fig. 4). Below the aquifer vertical fractures dominate, and the temperature gradient decreases. Below this section the horizontal fracturing dominates from 355 to $405 \mathrm{mbsf}$ (at the lower part of seismic Layer 2A).

In the lower part of the pillow lava sequence (405-550 mbsf, corresponding to part of seismic Layer $2 \mathrm{~B}$ ) a pronounced difference in fracturing is observed when compared to the pillow lava sequence down to 405 mbsf (Fig. 4). From 405 to 550 mbsf three major zones are identified where the fracturing is vertical. The first zone is located from 405 to $444 \mathrm{mbsf}$, and this zone is divided by a $1-\mathrm{m}$-thick element of horizontal fracturing at approximately $423 \mathrm{mbsf}$. The amount of vertical fracturing above 423 mbsf is about twice that of the region below. The second zone is located between 461 and $503 \mathrm{mbsf}$, and the third starts at $520 \mathrm{mbsf}$ and occurs within the $\mathrm{Na}-\mathrm{Ca}$ Zeolite alteration zone (Becker, Sakai, et al., 1988). These three major zones are separated by two distinct zones of horizontal fracturing $18 \mathrm{~m}$ and $14 \mathrm{~m}$ thick, respectively.

Overall, the temperature gradient 405-550 mbsf (in seismic Layer 2B) shows a stepwise behavior that correlates well with the fracturing style. Trends of the temperature gradient are shown in Figure 4 for the region of dominant vertical fracturing. The average temperature gradient in the horizontal fractured zones is not indicated as the uncertainty caused by a large lateral variation and lack of data points would not give a representative value for the zone. The thin zone dominated by horizontal fracturing found around $425 \mathrm{mbsf}$ does not seem to affect the temperature gradient in the first major zone ( $405-444 \mathrm{mbsf}$ ) in seismic Layer 2B. From 400 mbsf to $506 \mathrm{mbsf}$ the variation of the temperature gradient is less in the two zones dominated by vertical fracturing than in the horizontal zone in between (Fig. 4). The lowermost zone of vertical fracturing ( $518 \mathrm{mbsf}$ to $550 \mathrm{mbsf}$ ) consists of two parts. In both parts the temperature gradient shows less variation than in the horizontal fractured zone above (Fig. 4). The division into three vertical and two horizontal zones is represented in the stepwise appearance of the temperature gradient. The caliper data (Cann and Von Herzen, 1983) show a reasonable stable hole over the interval concerned with the temperature profile (Fig. 4). Zones with pronounced large borehole diameters are located in the underpressured aquifer, in the region between 400 and 430 mbsf with great vertical fracturing, and in a vertical fractured zone ( $463 \mathrm{mbsf}$ to $506 \mathrm{mbsf}$ ). It seems from the correlation between the caliper log and the fracturing mode that zones related to larger than normal borehole diameter mainly represent zones characterized by vertical fracturing. In the underpressured aquifer two maxima peaks in caliper log (325 mbsf, just below massive Unit 2D, and at $345 \mathrm{mbsf}$ ) correlate with two high value peaks in the temperature gradient showing a relationship between the borehole size, fracture porosity, and temperature gradient in the underpressured aquifer. The caliper anomaly in the zones 400 to $430 \mathrm{mbsf}$ and 463 to $506 \mathrm{mbsf}$, where vertical fractured zones dominate, does not show any correlation with the temperature gradient.

The behavior of the temperature gradient curve below about 375 mbsf can be summarized in terms of intervals within which the gradient shows a generally smooth trend in variation (increasing or decreasing), separated by distinct steps in the magnitude of the gradient. The latter are observed to correlate with zones in which horizontal fracturing is dominant, while the smoothly trending parts of the gradient curve correlate with zones characterized by vertical fracturing (Fig. 4).

\section{FRACTURING AND LITHOLOGY}

The relationship between the fracturing mode and the basaltic lithology down to Unit 27 is shown in Figure 4. The basalt units and the lithology are based on Cann, Langseth, Honnorez, Von Herzen,
White, et al. (1983, pp. 47-53), who divided the basalt into five groups, among which groups 1 through 4 are represented in the section found between 274 and $550 \mathrm{mbsf}$. The inversion of the temperature gradient of Leg 140 is located in Unit 1 and the uppermost part of Unit 2A, whereas the anomalous behavior of the temperature measurement at Leg 137 is found in Unit 2C. The less pronounced temperature gradient minimum of Leg 140 is located in the lowermost part of Unit 2D or the uppermost part of Unit 3A (Fig. 4). The maximum gradient is reached in the lower part of Unit $3 \mathrm{~A}$. The horizontal fractured zones that are interpreted to be important in the hydrological activity in the lower pillow lava sequence (in seismic Layer $2 \mathrm{~B}$ ) are related to the two intervals covered by the lower part of Unit 16 and the upper part of Unit 17, and Unit 21 and the upper part of Unit 22 (Fig. 4). The horizontal layered zone around $425 \mathrm{mbsf}$ corresponds to Units 10-15. The fracture porosity represented by the horizontal and vertical fracturing mode shows no correlations to the basalt lithology as represented by the basalt units.

The standard gamma-ray data, which includes the thorium, potassium, and uranium activity from Leg 111, were compared to the fracture porosity (Fig. 4) to see whether a correlation between these data was present. These logging curves were first smoothed with a nineterm moving average. Low values of total gamma represent zones where the original basalt is low in $\mathrm{U}, \mathrm{Th}$, and $\mathrm{K}$ or where these elements have been selectively leached. We assumed that a relationship between (1) low gamma-ray activity and high fracture density could imply relatively clean fractures open to fluid movement, and (2) high gamma-ray activity and high fracture density could imply that K-rich clay could be infilled in the fractures, hence the fractures were not open to free fluid circulation. In the aquifer ( 325 to $365 \mathrm{mbsf}$ ) three pronounced peaks located at $333 \mathrm{mbsf}, 340 \mathrm{mbsf}$, and $350 \mathrm{mbsf}$ represent great vertical and horizontal fracturing that correlates with three local minima on the gamma-ray data, indicating that the fractures are open and that fluid may move at these locations. These locations correlate with three local minima on the temperature gradient profile. At 510 to $518 \mathrm{mbsf}$ the horizontal fractured zone correlates to a local minima in gamma-ray activity, implying that the fractures might be open and the zone correlates to a higher temperature gradient than found above and below this interval.

In a zone characterized by horizontal fracturing ( 445 to $460 \mathrm{mbsf}$ ), gamma-ray activity increases, thus indicating that the fractures were filled with clay, which prevented free fluid circulation. Here the temperature gradient curve fluctuates. At $420 \mathrm{mbsf}$ and around $500 \mathrm{mbsf}$ two zones with great vertical fracturing correlate to local gamma-ray maxima, which indicate that open fractures and local temperature gradient minima are found here.

Overall, some relationship is found between fracturing and gammaray activity. In the aquifer the fractures seem to be open, allowing fluid circulation. In the two zones characterized by horizontal fracturing inferred to be associated with the temperature gradient, the upper zone ( 440 to $465 \mathrm{mbsf}$ ) seems to be filled, whereas the lower zone (508 to 515 mbsf) seems to be open.

\section{DISCUSSION}

The temperature curve obtained during reentry of Leg 140 showed a temperature inversion immediately below the sediment/basement interface and an irregular increase in temperature down to $550 \mathrm{mbsf}$. The corresponding temperature gradient curve, which reveals the temperature inversion as well as the more subtle changes in the temperature profile, shows stepwise variations in places. To shed some light on the behavior of the temperature and associated temperature gradient profiles we looked into possible correlations with some other logs, especially the electrical logs and the lithology of the basement section based on core description from Legs 69 and 70 .

The zone where the thermal gradient inversion (283-288 mbsf) measured at the reentry of Leg 140 is located corresponds to a zone where horizontal fractures dominate (Fig. 4). A similar zone where 
horizontal fractures dominate, just above the massive flow Unit 2D, which starts at $312 \mathrm{mbsf}$, was the location of the pronounced change in temperature gradient recorded at the reentry of Leg 137 (Fig. 4). The temperature reading shows that this zone was not active during reentry of Leg 140. In contrast, no particular change in temperature was noticed at the reentry of Leg 137 and Leg 140 from 300 to 310 mbsf, where the presence of vertical fracturing is indicated from the resistivity data. Thus the temperature variations that indicate the movement of fluids in that part of the basement located above Unit $2 \mathrm{D}$ are associated with the presence of a horizontal fracture network.

A thermal gradient minimum at $325 \mathrm{mbsf}$ is situated in a region where horizontal fractures dominate immediately below Unit 2D in the underpressured aquifer (Anderson and Zoback, 1982; Anderson, Honnorez, Becker, et al., 1985). The aquifer is highly porous with pronounced vertical and horizontal fracturing, which seem in places to be open fractures. Horizontal fractures are uniformly distributed in the 30-m-thick aquifer (Cann et al., 1983; Pezard, 1990) below the massive Unit 2D, whereas the density of vertical fractures tends to decrease with increasing depth away from Unit 2D. The temperature gradient is high in the aquifer and reaches its maximum in the $17-\mathrm{m}$ thick zone dominated by horizontal fracturing in the lower part of the aquifer (Fig. 4). This positive anomaly of the thermal gradient may indicate fluid flow activity (from the borehole into the formation) or differential thermal recovery from the effects of the Leg 137 inflow.

The lower part of the pillow lava sequence from 405 to $550 \mathrm{mbsf}$ (upper part of seismic Layer 2B) is divided into vertical fractured zones, with fairly constant average values of the temperature gradient, separated by regions of horizontal fractures. The temperature gradient indicates that some hydrological activity, albeit small, may take place in the horizontal fractured zones. The gamma-ray activity indicates that the upper horizontal fractured zone may be partly filled with clay, whereas the lower seems to be open. The deepest of the vertical fractured zones starting from approximately $520 \mathrm{mbsf}$ is located below the lower horizontal fractured zone and is characterized by a distinct paleoflow regime, with the presence of sodic and calcic alteration (mostly zeolites) observed in rocks from this interval (Alt et al., 1986).

In the upper part of the hole at the intersection between sediments and basement the temperature gradient measured at the reentry of Leg 140 is nearly constant $\left(-250^{\circ} \mathrm{C} / \mathrm{km}\right)$ over a $5-\mathrm{m}$ interval (Fig. 4$)$. This interface is the zone of higher-than-average natural gamma-ray values that also occurs in Holes 501, 504A, and 505 (Cann and Von Herzen, 1983). These intervals have high gamma-ray values relative to the underlying basement, reflecting the presence of $\mathrm{K}, \mathrm{Th}$, and/or $\mathrm{U}$, and are indicative of more altered basalt due to past and/or present fluid circulation. The constant values of the temperature gradient recorded at the reentry of Leg 140 do not indicate fluid circulation along the sediment-basement interface at the time of the reentry, and the zone thus seems to represent a former hydrological system. Present and former hydrological systems are thus present in Hole 504B.

The temperature vs. depth and the temperature gradient vs. depth curve show that changes in temperature in the watermass in Hole 504B exist, and these changes correlate with the mode of horizontal fracturing (Fig. 4). The changes could be caused by active or passive processes or a combination. The active processes may be fluid flow activity within the basement, and passive may be differential recovery of the water column after the Leg 137 downflow. Above $350 \mathrm{mbsf}$ the temperature readings conducted on reentry to Hole 504B since 1979 indicate that the fluid flow affects the temperature. The fluid flow activity, in turn, may relate to tectonic processes that could have reactivated older fault systems or created new systems that have opened new circuits for the hydrologic activity. Below 350 mbsf the changes in temperature are less pronounced, and fluid flow activity, as in the upper $350 \mathrm{mbsf}$, is not detected. A simpler explanation may be that the thermal recovery of Hole 504B to the downflow detected at Leg 137 differs below $350 \mathrm{mbsf}$, and this could be the explanation for the correlation between the temperature gradient curve and horizontal fractur- ing. Alternatively, watermasses related to the downflow detected at Leg 137 could have moved into the formation and are now moving back toward the lower pressure region represented by the borehole.

To increase the understanding of the behavior of the temperature in Hole $504 \mathrm{~B}$ as a result of active and/or passive processes, we suggest that calculations on fluid flow should be undertaken to determine the time needed for the temperature profile to recover with the regional geothermal gradient. In addition, temperature profiles obtained at the reentry of Hole 504B since 1979 should be re-analyzed and correlated to fracturing systems, flowmeter measurements should be performed during future reentries to Hole 504B, and the seismic activity of the region should be correlated with the reentry of Leg 137.

\section{CONCLUSION}

At the reentry of Leg 140 into Hole 504B, temperature readings were performed to a depth of $550 \mathrm{mbsf}$, and a temperature inversion between 283 and $288 \mathrm{mbsf}$ was detected. The analysis of the temperature vs. depth and temperature gradient vs. depth profiles showed a correlation between fracturing and temperature gradient. Based on the analysis of these data, we point out that variations in temperature as revealed by the temperature gradient curve could be because of fluid movement or differential recovery due to the downflow recorded at the reentry of Leg 137. In the upper part of the basement above $320 \mathrm{mbsf}$, hydrological activity has been reported on earlier occasions, and we suggest that the temperature inversion at the reentry of Leg 140 could be due to renewed hydrological activity either because of reactivation of faults or tectonic activity that has opened new circuits. Below 320 mbsf the variations in temperature as shown by the temperature gradient curve are rather small, and as no fluid activity caused from currents within the basement have been reported, it seems that the simplest explanation is differential recovery of the water column from the water inflow reported from Leg 137. Alternately, although more tentative, the temperature variations may be ascribed to fluid, which was squeezed into the horizontally fractured system during the inflow associated with Leg 137, and is now moving back into the lower pressure environment assumed to be found in the borehole.

\section{ACKNOWLEDGMENTS}

The authors thank H. Villinger, E. Davis, J. Sclater, and K. Becker for critical reading of the manuscript and comments.

\section{REFERENCES}

Alt, J.C., Honnorez, J., Laverne, C., and Emmermann, R., 1986. Hydrothermal alteration of a $1 \mathrm{~km}$ section through the upper oceanic crust, Deep Sea Drilling Project Hole 504B: mineralogy, chemistry, and evolution of seawater-basalt interactions. J. Geophys. Res., 91:10309-10335.

Anderson, R.N., Honnorez, J., Becker, K., Adamson, A.C., Alt, J.C., Emmermann, R., Kempton, P.D., Kinoshita, H., Laverne, C., Mottl, M.J., and Newmark, R.L., 1982. DSDP Hole 504B, the first reference section over $1 \mathrm{~km}$ through Layer 2 of the oceanic crust. Nature, 300:589-594.

Anderson, R.N., Honnorez, J., Becker, K., et al., 1985. Init. Repts. DSDP, 83: Washington (U.S. Govt. Printing Office).

Anderson, R.N., and Zoback, M.D., 1982. Permeability, underpressures, and convection in the oceanic crust near the Costa Rica Rift, eastern equatorial Pacific. J. Geophys. Res., 87:2860-2868.

Becker, K., Foss, G., et al., 1992. Proc. ODP, Init. Repts., 137: College Station, TX (Ocean Drilling Program).

Becker, K., Langseth, M.G., and Von Herzen, R.P., 1983a. Deep crustal geothermal measurements, Hole 504B, Deep Sea Drilling Project Legs 69 and 70. In Cann, J.R., Langseth, M.G., Honnorez, J., Von Herzen, R.P., White, S.M., et al., Init. Repts. DSDP, 69: Washington (U.S. Govt. Printing Office), 223-236.

\footnotetext{
-Abbreviations for names of organizations and publications in ODP reference lists follow the style given in Chemical Abstracts Service Source Index (published by American Chemical Society).
} 
Becker, K., Langseth, M.G., Von Herzen, R.P., and Anderson, R.N., 1983b. Deep crustal geothermal measurements, Hole 504B, Costa Rica Rift. $J$. Geophys. Res., 88:3447-3457.

Becker, K., Langseth, M.G., Von Herzen, R.P., Anderson, R.N., and Hobart, M.A., 1985. Deep crustal geothermal measurements, Hole 504B, Deep Sea Drilling Project Legs 69, 70, 83, and 92. In Anderson, R.N., Honnorez, J., Becker, K., et al., Init. Repts. DSDP, 83: Washington (U.S. Govt. Printing Office), 405-418.

Becker, K., Sakai, H., Adamson, A.C., Alexandrovich, J., Alt, J.C., Anderson, R.N., Bideau, D., Gable, R., Herzig, P.M., Houghton, S.D., Ishizuka, H., Kawahata, H., Kinoshita, H., Langseth, M.G., Lovell, M.A., Malpas, J., Masuda, H., Merrill, R.B., Morin, R.H., Mottl, M.J., Pariso, J.E., Pezard, P.A., Phillips, J.D., Sparks, J.W., and Uhlig, S., 1989a. Drilling deep into young oceanic crust, Hole 504B, Costa Rica Rift. Rev. Geophys., 27:79-102.

Becker, K., Sakai, H., et al., 1988. Proc. ODP, Init. Repts., 111: College Station. TX (Ocean Drilling Program).

1989b. Proc. ODP, Sci. Results, 111: College Station, TX (Ocean Drilling Program).

Cann, J.R., Langseth, M.G., Honnorez, J., Von Herzen, R.P., White, S.M., et al., 1983. Init. Repts. DSDP, 69: Washington (U.S. Govt. Printing Office).

Cann, J.R., and Von Herzen, R.P., 1983. Downhole logging at Deep Sea Drilling Program Sites 501, 504, and 505, near the Costa Rica Rift. In Cann, J.R., Langseth, M.G., Honnorez, J., Von Herzen, R.P., White, S.M., et al., Init. Repts. DSDP, 69: Washington (U.S. Govt. Printing Office), 281-300.
CRRUST (Costa Rica Rift United Scientific Team), 1982. Geothermal regimes of the Costa Rica Rift, east Pacific, investigated by drilling, DSDP-IPOD Legs 68, 69, and 70. Geol. Soc. Am. Bull., 93:862-875.

Dick, H.J.B., Erzinger, J., Stokking, L.B., et al., 1992. Proc. ODP, Init. Repts., 140: College Station, TX (Ocean Drilling Program).

Gable, R., Morin, R.H., and Becker, K., 1989. Geothermal state of Hole 504B: ODP Leg 111 overview. In Becker, K., Sakai, H., et al., Proc. ODP, Sci. Results, 111: College Station, TX (Ocean Drilling Program), 87-96.

Leinen, M., Rea, D.K., et al., 1986. Init. Repts. DSDP, 92: Washington (U.S. Govt. Printing Office).

Pezard, P., 1990. Electrical properties of mid-ocean ridge basalt and implications for the structure of the upper oceanic crust in Hole 504B. J. Geophys. Res., 95:9237-9264.

Pezard, P.A., and Anderson, R.N., 1989. Morphology and alteration of the upper oceanic crust from in-situ electrical experiments in DSDP/ODP Hole 504B. In Becker, K., Sakai, H., et al., Proc. ODP, Sci. Results, 111: College Station, TX (Ocean Drilling Program), 133-146.

Date of initial receipt: 2 April 1993

Date of acceptance: 28 March 1994

Ms 137/140SR-032 